\title{
Polities and nomads: the emergence of the Silk Road exchange in the Tarim Basin region during late prehistory (2000-400 $\mathrm{BCE})$
}

\author{
Tomas Larsen Høisæter \\ University of Bergen \\ tomashoisaeter@gmail.com
}

\begin{abstract}
The Silk Road trade network was arguably the most important network of global exchange and interaction prior to the fifteenth century. On the question of how and when it developed, scholars have focused mainly on the role of either the empires dominating the two ends of the trade network or the nomadic empires on the Eurasian steppe. The sedentary people of Central Asia have, however, mostly been neglected. This article traces the development of the city-states of the Tarim Basin in eastern Central Asia, from c. $2000 \mathrm{BCE}$ to $400 \mathrm{BCE}$. It argues that the development of the city-states of the Tarim Basin is closely linked to the rise of the ancient Silk Road and that the interaction between the Tarim polities, the nomads of the Eurasian steppe and the Han Empire was the central dynamic in the creation of the ancient Silk Road network in eastern Central Asia.

Keywords: Silk Road, Trade networks, Eastern Central Asia, Tarim Basin in prehistory, Xinjiang, Development of trade networks
\end{abstract}

The Silk Road is one of the most evocative and stirring terms invented for something as mundane as the exchange of resources, and the term is certainly one that students of Central Asian history cannot avoid. Yet in 1978 an article entitled "New studies in Roman commerce with the East" by Manfred Raschke questioned the very existence of a grand trade network such as the Silk Road. He postulates instead that the spread of Chinese goods eastwards and vice versa was the result of a series of small-scale exchanges between various nomadic groups of the Eurasian Steppe (Raschke 1978). While his assertion that no network existed in antiquity has been challenged by archaeological discoveries ${ }^{1}$ and literary evidence from both Roman and Chinese sources (e.g. Pliny, N.H., Book VI, Chapter XX; Fan Ye, 88 (55)), Raschke did raise the important question of who, or rather what mechanism, drove exchange across Eurasia. And implicit in this lies the question of when it started. Most scholars prior to Raschke viewed the great empires of antiquity as the instigators and enforcers of the early Silk Road trade network, imagining the Chinese and Romans as the primary

1 For an example the pass-notes written on wooden slips issued to foreign traders at the border of the Han Empire (see Wang 2004: 58). 
suppliers and buyers respectively, with the Parthian and sometimes Kushan empires as "middlemen", monopolizing and profiting from this long-distance trade. (Varieties of this explanation are presented by Boulnois 1966; Thorley 1979, 1971, 1969; Ferguson and Keynes 1978; Liu 2010; and McLaughlin 2010). In this "traditional" narrative, the opening of the Silk Road trade network is usually dated to the end of the second century BCE, specifically to Zhang Qian's first expedition towards the west in around 138 BCE. Others have connected it to the Han general, Li Guangli's, first military expedition into the Tarim Basin towards Dayuan (Ferghana) in 104 BCE.

Several other scholars, especially those focusing on the Central Asian Bronze Age or the history of the vast Eurasian steppe zones, have emphasized the role of the steppe peoples of Central Asia in the Silk Road trade network. In the steppefocused narrative, the exchange between various nomadic and semi-sedentary groups of the Eurasian steppe are seen as the driving forces of the Silk Road trade network. In particular, Christopher Beckwith's account emphasizes the large confederations of nomadic groups in the second half of the first millennium BCE (Beckwith 2009, ch. 2 and 3). Similar theories are presented by Anthony 1998; Davis-Kimball 1998; and Kuzmina 2008, among others. The period singled out as the start of exchange across Eurasia is in these accounts far more varied and nuanced, with several scholars emphasizing its origin in local exchange and dates ranging from the second millennium $\mathrm{BCE}$, proposed by Anthony (1998: 109), to Beckwith's mid-first millennium BCE (2009: 59).

Both of these approaches have clear merits and have advanced the field immensely: the latter tradition in particular, with its focus on the people living in Central Asia. Yet the attempt to discover the one major and final actor or driving force in the creation of the Silk Road network has proved to be a futile endeavour. Not only do many of these accounts fail to recognize the dynamic relationships between the nomadic and settled actors, but they have also tended to explain any changes taking place across Central Asia as the result of wholly external factors, be they the civilizing influence of the Chinese, or nomadic migration from the west. Arising partly from the latter traditions focusing on small-scale exchange and the role of pastoral nomadism, as pioneered by Raschke, most recent scholars recognize partly or wholly that the Silk Road trade network arose due to the connecting of several far older local or regional trade networks. In the field of Silk Road history such a view is particularly exemplified by David Christian in "Silk roads or steppe roads? The Silk Road in world history" (2000), and more recently by Di Cosmo ("A note on the formation of the 'Silk Road' as long-distance exchange network", 2014). A similar focus on small-scale exchange was also recently presented by Valerie Hansen in her book The Silk Road: A New History, though this work is mainly focused on later periods (Hansen 2012: 8-11). Several recent archaeological studies have also emphasized the importance of these older networks, for both the diffusion of nomadic "technology" and culture across Eurasia and also for the formation of nomadic polities (Frachetti 2002, 2012, 2011; Honeychurch 2015). As Frachetti puts it:

Such rethinking is timely because new archaeological findings from central Eurasia enable us to explore the intricate interrelationships among 
regionally conscribed societies whose microeconomy was independently motivated yet whose macroeconomy grew networks over unprecedented scales (Frachetti 2012: 21)

With this view in mind when searching for the mechanism and forces which saw the rise of the Silk Road trade network, it seems to me far more fruitful to look at the interaction of the various groups later active in the network: both the traditionally recognized empires and nomadic polities, but equally important, the other polities and groups found along the Silk Road network. This article will look at what later became an important stretch of this network: the Tarim Basin and the surrounding mountain regions. It attempts to answer the question of the role the groups living in the Tarim region played in the development of what this article calls "The Eastern Central Asia trade network". In order to discuss this question I will put forward two research questions inspired by the basic inquiry formulated in Honeychurch (2015) on the development of nomadic polities and empires, though reiterated to suit the objectives of this article. (1) How did local conditions change by being introduced into a regional and/or interregional context (i.e. exchange network); and (2) how did local developments impact the regional and/or inter-regional context/exchange?

\section{The Tarim Basin}

The Tarim Basin ${ }^{2}$ was, at the time the Chinese entered the region in $104 \mathrm{BCE}$, occupied by some 36 independent kingdoms according to Chinese sources: some oasis-based agricultural communities and others nomadic or semi-nomadic polities living in the surrounding mountains and steppe regions. The oasis-based communities had at the time developed into fully fledged city-states based on irrigated agriculture and pastoral products from the surrounding hinterland. Archaeology has shown (Debaine-Francfort et al. 2010: 193-5) that some of the cities were walled and capable of mustering an army in their defence, and ruled by a king presiding over an institutionalized bureaucracy (Hansen 2012: 45-50). Probably not self-sufficient within their own territories, these city-states relied upon both exchange with neighbours and on long-distance connections to acquire important materials such as foodstuffs, minerals and especially luxuries such as silk or gold (Di Cosmo 2000: 405-6). These shared characteristics fit them seamlessly into the model for what one may term a city-state provided by Mogens Hansen (2000: 17-9).

This article argues that these city-state-like polities in and around the Tarim Basin played a crucial role in the establishment of the eastern part of the Silk Road, and that the development in this region gives a good example of the dynamics which in all likelihood saw the rise of the Silk Road trade network. In order to argue this case the article will trace the rise of the Tarim Basin

2 As discussed by Helen Wang (2004: 3), the area is given several different names in the scientific literature: Xinjiang, Eastern Turkestan and Wang's own Eastern Central Asia, to name just a few. I have chosen to use Tarim Basin area in this article when referring to the Tarim Basin and surrounding mountainous regions in historical time, as the term conveys an exact geographic location. 
polities from the Bronze Age, roughly 2000 BCE, until the end of Tarim prehistory in the latter half of the first millennium BCE, with a particular focus on connections and forms of exchange, both regional and long-distance contacts. It will endeavour to show that a change takes place towards the end of the second millennium BCE as the region grows more interconnected and long-distance contact is established, coinciding with the introduction of both ironworking and horseriding technology, but also Chinese luxury items, into the Tarim Basin. It will therefore be argued that the predecessor of the Silk Road trade network in Eastern Central Asia, what this article terms the Eastern Central Asia trade network, originates from this period and formed part of the foundation for the emergence of the larger Silk Road trade network.

As the Tarim Basin region is vast, I have chosen two areas to exemplify the development seen across the region: the oasis areas Chinese sources termed Yanqi (Karashar); and Jumi (Keriya) - although adjacent areas will also be touched upon. Yanqi (Karashar), nestled in a deep valley between tall mountains on the shores of Baghrash Kul (Lake Bositeng), lies on the border between the Tarim Basin and the Eurasian steppe along the northern rim of the Tarim Basin. The area has archaeological evidence stretching back to the second millennium BCE, occupied first by the Xintala (c. 1700-1500 BCE)(Chen and Hiebert 1995: 267) and later the Chawuhugoukou culture (c. 1000-400 BCE)(Chen and Hiebert 1995: 275), and is thus ideal for exemplifying the development of the Tarim polities. Jumi (Keriya), on the other hand, was a large and fertile oasis-area situated along the southern rim of the Tarim Basin along the Keriya River. The ancient Keriya delta is the site of the oldest city discovered in the Tarim Basin, called Djoumboulak Koum (mid-first millennium BCE)(Debaine-Francfort et al. 2010: 193) and gives an intriguing insight into the region's development during the late prehistoric period (see Appendices 1 and 2).

A theoretical distinction between the various "levels" on which exchange can operate is also necessary, in order better to distinguish the various forms of exchange of resources seen in the period under discussion. The three categories, which certainly overlap extensively, are gift-exchange, local exchange, and long-distance exchange. In this context, gift-exchange means the simple giving of a gift from one person or group to another, a form of exchange characterized by no direct exchange but heavy social connotations and often expected returns in the form of either resources or obligations. Local exchange denotes the more trade-like practice of exchanging a resource for another, sometimes through a form of currency, but freed of the heavy social connotations of gift-giving. Local exchange could be more organized, with set times and locations for meeting, or more random and spontaneous. The intentions behind gift-exchange and local exchange are also usually different. Finally, long-distance exchange denotes the practice of exchanging resources directly with distant groups, requiring far more organization than local exchange, as the distances involved were far greater, thus requiring a fixed meeting or market place, a network to support the traversing of vast distances, etc. Often such exchange would go through a medium such as currency, or a resource such as silk being used as currency, though this would not always have been the case. In addition to these three forms of exchange this article will also use the terms regional and interregional exchange to denote the spatial scale on which the exchange takes place. Both 
scales incorporate gift-giving and local exchange, while long-distance exchange is by definition interregional.

Finally, a few notes on chronology and transcription are necessary. Though a more tightly meshed chronological framework for the region is needed, this article follows Chen and Hiebert's separation of late Tarim Basin prehistory into an early (c. 2000-1000 BCE) and late (1000-400 BCE) period (Chen and Hiebert 1995). ${ }^{3}$ These correspond very roughly with the Bronze Age and the late Bronze Age/early Iron Age of the Tarim Basin area. Various authors use slightly different transcriptions for various Chinese place names in the Tarim Basin but I have, as far as possible, attempted to follow the modern pinyin spelling throughout, without tonal marks. When discussing ancient oases I have used the name from the Chinese sources followed by the modern name in brackets, following the example of Hill's (2015) translations.

\section{First phase - the first settlements}

\section{The settlements}

Based on our current knowledge, human habitation of the Tarim Basin stretches back to almost 8000 BCE with finds of Stone Age remains and implements found at both the Gouxi site in the Turfan basin and at Astana near modern Gaochang city (Jiang et al. 2013: 129). By the beginning of what Chen and Hiebert term the early period of Tarim prehistory (2000-1000 BCE), the use of bronze started appearing in the Tarim Basin and archaeological excavations have yielded several different "cultural zones" spread over several different sites. For the early period, Chen and Hiebert suggest six different cultural zones (1995: 250). These are mainly differentiated on differences in burial practice, pottery traditions and metalworking styles, yet are found to have largely shared several traits such as sustenance basis, resource exploitation, technology and likely also social structures (Chen and Hiebert 1995).

The Xintala culture (radio-carbon dated 1700-1470 or 1680-1490 BCE)(Chen and Hiebert 1995: 267; IAX 1988) was situated close to the later location of the kingdom of Yanqi (Karashar) and is a good example of the shared traits of the Tarim Basin cultures. The site, which sits upon a terrace of the Kaidu River valley, is thought to have been settled and to have served as a place of burial, though no intact burials have been found so far. The location itself is typical of the Tarim cultures, nestled by the foot of the northern Tian Shan range with access to both the rich alluvial soil of the river valley and the highland areas ideal for herding. Its location, near a natural crossing point of the Tian Shan, also allowed contact with both the Tarim Basin and the steppe region to its north (Chen and Hiebert 1995: 265). Analysis of the sediment and seeds found at the site show that the Xintala people lived by farming wheat and millet, remains of which have been found at the site (Zhao et al. 2013: 81-6). Due to the Tarim Basin's severe aridity, dry farming would not have been possible and it seems likely, as suggested by Chen and Hiebert (1995:

3 I have chosen not to follow Zhimin An's separation of the first phase into two separate periods, an early and late Bronze Age, as it serves no practical purpose in this article. For Zhimin An's periodization see An 1998: 55-8). 
245-7), that the people of the Tarim Basin lived in irrigated oases sited on natural river deltas from early times. In the case of Xintala this has been proven by analysis of the sediments from the site, which indicate human irrigation, a process which over time led to raised soil salinity and possibly the abandonment of the site (Zhao et al. 2013: 85). High levels of typha pollen suggest that typha or cattail was frequently used by the Xintala people, perhaps for thatching or weaving (Zhao et al. 2013: 84). Herding livestock must also have been an important part of the sustenance basis, as shown by bone remains also found at Xintala (Romgard 2008: 14). This suggests a mixed diet, which seems to have been common across the entire Tarim Basin (Wagner et al. 2011: 5). The pottery was, like much of that found in the Tarim Basin, painted and decorated with patterns. At Xintala white slipped redware with purple-brown decorations, often triangles or zigzags, dominated (Chen and Hiebert 1995: 267). This is distinctly different from the surrounding cultural zones, for example the roughly contemporary Yanbulake pottery dominated by black on red with wavy lines and S-shapes (Chen and Hiebert 1995: 262). Other material remains from Xintala, however, show many similarities with the other Tarim Basin finds of the same period, mostly consisting of bones or stone artefacts with rarer occurrences of copper or bronze. The Xintala site has yielded copper and bronze objects such as arrowheads, a celt, a socketed axe and a knife as well as other basic tools (Chen and Hiebert 1995: 265; Mei and Shell 1998: 583-6). A copper knife and copper awl were discovered in the lower cultural layer, showing that copper technology was in use for a long time at the site (Mei and Shell 1998: 584). Also, unlike other Tarim sites, stone moulds for copper (Mei and Shell 1998: 585) and bronze casting were discovered (Chen and Hiebert 1995: 265), which Mei and Shell suggest proves that the bronze objects were crafted locally. As both copper and tin were available in the mountains near the Yanqi (Karashar) oasis (Mei and Shell 1998: 594), such a hypothesis does not seem unreasonable. As for more luxurious items - gems, etc. - the finds are very limited, but nephrite jade in the form of an axe was discovered at the site (Chen and Hiebert 1995: 265). Structures built with mud bricks were found at Xintala, similar in construction to the mud brick technique seen in early oasis settlements in Western Central Asia, but also with parallels in the Yanbulake site (Chen and Hiebert 1995: 267). There have been no burials uncovered so far in the Xintala zone but looking at the finds of graves at, for example, neighbouring Yanbulake, the populations of these settlements must also have been quite small and seemingly fairly egalitarian.

Indeed, judging from the burial practices and graves found in the Tarim region as a whole, it seems the social stratification must have been quite limited across the whole region. As societies based on irrigated agriculture one would perhaps have assumed a higher level of social stratification and complexity, necessary for organizing the communal work that irrigation requires. However, this is not reflected in the archaeological material and may not in fact be the case due to the use of a system of smaller channels $(50-150 \mathrm{~cm}$ wide) in an intricate network, which would allow smaller "clan-type" social units to irrigate large plots of land without the need for a more complex society. Just such a system was discovered at Djoumbulak Koum in the Jumi (Keriya) delta (Debaine-Francfort et al. 2010: 196). Burial sites, discovered at 
Gumugou, Yanbulake and Aidinghu, show a variety of burial practices across the region, but the tombs are relatively uniform in content, with few prestige items, and very little in the way of monumental graves (Chen and Hiebert 1995: 250-65). Several Yanbulake burial sites contain tombs with several people buried together (Chen and Hiebert 1995: 262), while Aidinghu sites have yielded burials containing two individuals (Chen and Hiebert 1995: 264), and though communal burials do not necessarily mean a lack of stratification in a society, they do often indicate a focus on the community rather than the individual. These burial practices, taken together with the very limited number of prestigious items seen at the Xintala and Haladun sites (Chen and Hiebert 1995: 265), suggest a low level of social stratification and fairly egalitarian societies in the early Tarim oasis settlements.

\section{Regional exchange and interaction}

Returning to the central question of exchange and interaction, regional contact between the Tarim settlements as well as interregional contact with groups outside the Tarim Basin is hotly debated in the field of the prehistoric Tarim Basin's history, and several different types of interaction have been proposed, the most prominent being exchange, migration, and the transmission of technology. The nephrite jade used in an axe found at Xintala, for example, probably originated from elsewhere in the Tarim Basin, possibly the jade-rich areas in the Kunlun Mountains. A golden ear pendant with an agate bead, as well as cowry shells, at the Yanbulake site, similarly suggest regional and even interregional exchange, as these are unlikely to be local products. However, finds of this kind from excavated sites are rare across the Tarim region, suggesting this exchange must have been infrequent: it could have been connected to intermarriage between different groups or been the result of some form of gift-exchange, perhaps even part of a more regular regional exchange system or network. Looking at other possible resources for exchange, both tin and copper are abundantly available across the Tarim Basin as well as in adjacent regions such as the Altai mountains and the Ili valley (Mei and Shell 1998: 594; Penhallurick 2008: 35). The central plains regions of China already had a well-developed bronze civilization (Mei et al. 2015: 222), and some jade from the Tarim Basin is known to have appeared in China during this period (Mei and Shell 1998: 593), suggesting a possible link. Yet judging from the lack of foreign novelties in the Tarim Basin sites, it does not seem that bronze utilization triggered the long-distance exchange and state formation processes seen, for example, in the Eastern Mediterranean. Rapp (2009: 175) points out that the heartland of the early Chinese bronze civilizations had a ready supply of tin at nearby sites. This, however, would probably have led to some regional exchange between resource-rich and poor areas, and Mei and Shell (1998: 597) even suggest there might have been a limited number of centres producing most of the Tarim region's copper and bronze items. Regional exchange based on metallurgy is also proposed by Michael Frachetti (2002: 165-6), who suggests that control of this growing exchange may have been one of the main reasons for some communities adopting semi-sedentary or wholly nomadic ways of life in the areas north of the Tian Shan mountains towards the end of the second millennium BCE. If correct, this would have fostered an important, if basic, network 
of regional contact and exchange, though seemingly very limited in scope and distances crossed.

Perhaps the most disputed aspects of Tarim prehistory are questions of migration and ethnicity, several recent works on the Tarim Basin Bronze Age period having focused on the ethnicity of early inhabitants. This is mainly related to the discovery of several mummies with distinct Caucasian or Europoid features. ${ }^{4}$ Some scholars have proposed an influx of Indo-Europeans from the west around the beginning of the second millennium BCE (Mair 1995), more specifically the Afanasievo or Andronovo culture has many stylistic similarities with later Tarim Basin finds, and which has been proven to have existed to the north of the Tarim Basin during this period (Kuzmina 1998; Peng 1998). This is further supported by the known presence of Tocharian, an Indo-European language, in the Tarim Basin in the sixth century CE. Other scholars have proposed immigration from the Bactria-Margiana area (Chen and Hiebert 1995: 286-7), based on the shared oasis settlement model and similarities in livelihood and resource exploitation. However, the most recent craniometrical studies on the mummified remains found in the Tarim Basin have shown no close affinity to either of the two areas suggested, probably indicating that the influx of Caucasian people into the Tarim Basin occurred earlier (Hemphill and Mallory 2004: 217-8), while the study by Tan et al. (2013: 305) shows that the Bronze Age saw an influx of people which seems to have come from the east rather than, as previously thought, from the north and west. Regardless of direction, it is likely that population admixture occurred to some extent in the Tarim Basin during the second millennium $\mathrm{BCE}$, meaning people must have moved and interacted both within and beyond the Tarim region.

The origin of several techniques and technologies utilized by the Bronze Age inhabitants of the Tarim Basin has been discussed extensively in the literature. Han (2012) pointed out the similarities between Tarim Basin painted pottery traditions and those of central China, proposing that an "ancient pottery road" had reached the Tarim Basin and brought painted pottery techniques from central China. Metallurgical techniques for working copper and bronze could also have originated in the region. Zhimin An (1998: 59-60) suggests that the technology spread from West Asia, but Mei and Shell (1998: 594) point out that metal amulets and seals, common in West Asian assemblages, are not present in the Tarim Basin material. Instead they point out that the stone cast technique is similar to that used in the Steppe region (Mei and Shell 1998: 588) which, taking into account the stylistic similarities, seems likely. It is of course also entirely possible that these techniques were invented independently of the surrounding regions. However, similarities in style and technique with areas both north and west of the Tarim Basin make it seem likely that the local technology was related to, or had at least been influenced by, these areas.

But while these theories are tantalizing, none of these processes - the movement of people or the transmission of pottery painting and metallurgical techniques - have left much trace of permanent connections in the archaeological

4 See Romgard (2008) for a thorough discussion of the topic, Mair (1995), an advocate of the Tocharian theory, and Tan et al. (2013) for a recent discussion on population admixture. 
material. The proposed "painted pottery road" did not, for example, bring with it into the Tarim Basin other characteristic Chinese goods such as silk, which has not been discovered in early Tarim Basin burial sites despite the excellent preservation conditions prevalent in the area. One must thus assume that these processes, if they occurred, took place over a long period of time and in a manner that did not leave permanent connections of exchange or contact of a type which could meaningfully constitute a network. Indeed, the archaeological material of the Tarim Basin gives few clear indications of contact with regions beyond their immediate neighbours in this early period, and even regional exchange appears limited. The former is clearly seen in the lack of material remains, especially novelties such as silk, golden objects, etc., from beyond the Tarim Basin, these objects, as stated above, being limited to just a few specimens. The limits of regional exchange, on the other hand, are clearly seen in the lack of standardization between neighbouring assemblages, perhaps most clearly in very distinct pottery and burial cultures. To summarize, exchange of both resources and technology seems to have taken place, but mainly locally and on a small scale, probably moving from settlement to settlement over short distances.

The main reason for this lack of long-distance contact, as well as the seemingly low level of regional interaction, probably lies in the topographic conditions of the Tarim Basin. With settlements located in oasis regions in a wide circle around the Taklamakan desert, often sheltered in valleys of the surrounding mountains, communication between them must have been a task riddled with challenges. The difficulty of crossing the region's deserts, mountainous regions and large stretches of wasteland was noted by several authors and travellers, both ancient and more modern. ${ }^{5}$ While the difficult regions surrounding the oases, given an incentive, could certainly have been crossed, there seems to have been little internal demand to drive frequent exchange or contact over longer distances. With the possible exception of some metals, most resources were produced locally. The apparent lack of social elites would have further compounded this, as the resources to organize such an undertaking would not have been readily available to any one individual.

The Tarim Basin in the second millennium BCE, known to us through sites like Xintala, appears to be a region dominated by several small settlements sharing some broad characteristics but also displaying variations in mortuary practice, pottery styles, etc. Though probably based on a combination of irrigated agriculture and animal husbandry, these settlements display a low level of stratification and, based on the archaeological material available, appear to have been relatively egalitarian societies. Finds from Xintala and other sites show that there must have been regional contact and exchange within the Tarim Basin itself, which is displayed not least through shared resource exploitation strategies and cultural traits, though the scale seems to have been quite limited. This is shown by distinct cultural assemblages and burial practices in the various "zones", but perhaps more strongly by the lack of items and artefacts from beyond the immediate region. The exchange that took place across the Tarim

5 Ban Gu (1996: 96A [110]) describes how "... our envoys clasp the emblems of mighty Han and starve to death in the hills and valleys"; while Sir Aurel Stein (1903) describes on several occasions the harshness of the regions between the Oases. 
Basin must have been limited mainly to gift-giving and local exchange, taking place on a small scale between neighbouring areas. Metals such as copper and tin likely played a role in this regional exchange, as did a few novelty items such as jade or cowry shells. Interregional contact and exchange probably also took place, but appear limited in scope both quantitatively and spatially. It is not, as has been suggested by some scholars, the first example of the Silk Road trade network, as there are virtually no signs of long-distance exchange, but it should be seen rather as a precursor to the network that later developed. Of great interest, however, are some of the lines of interaction and exchange visible in this early period. Both the connections across the Tian Shan suggested by Mei and Shell (1998) and Frachetti (2002), and the possible connection to the Gansu area and through it the Chinese Central Plains suggested by Han (2012) would develop into important routes of exchange, as seen in the following section.

\section{Second phase - the development of the Tarim polities}

The late Bronze Age and early Iron Age in Tarim Basin prehistory (until the region enters Chinese written sources), a period from roughly 1000-400 BCE, stands in sharp contrast to the early settlement period described above. Rich archaeological material dating from this period has been discovered on several sites throughout the Tarim Basin, on previously inhabited sites but also in areas without earlier finds. The Xintala culture in the Yanqi (Karashar) oasis is replaced by the Chawuhu culture (RC dated 1000-400 BCE) (XAT (Xinjiang Archaeology Team) 1990a, 1990b, 1988), while in the Kunlun Mountains along the Keriya river near the Jumi (Keriya) oasis, the Liushiu cemetery (RC dated 1100-900 BCE) (Wagner et al. 2011) and the city of Djoumboulak Koum (fifth-first century BCE) developed (Debaine-Francfort et al. 2010), both very much exemplifying the changes seen across the Tarim Basin. The new "archaeological zones" are also larger than previously thought, the Chawuhu culture for example extends north-west to the Alagou sites at the edge of the Turfan basin and north to the area near Urumqi. The cemetery of Qunbake is also included by some in the Chawuhu zone based on the similar assemblage (Mei and Shell 1998: 591). Another new "archaeological zone" called Sidaogou roughly covers the areas once inhabited by the people of the Yanbulake and Aidinghu cultures in the Turfan basin. In this period the archaeological evidence undergoes significant changes as burial practices drastically change, grave goods increase, the occurrence of foreign items grows more common and the first polities start to appear.

\section{Yanqi - stratification, exchange and the steppe package}

In the Yanqi (Karashar) oasis, the Chawuhu site has furnished several cemeteries composed of fields of kurgan burial mounds with surrounding stone walls, making this site by far the largest discovered in the Chawuhu zone. The burial sites are far more monumental than anything previously seen in the area. The burials themselves were secondary burials ${ }^{6}$ with as many as 30 people interred in one

6 I.e. people having first been interred elsewhere and then reburied in communal burials. 
tomb, a pattern similar to the communal burials of the earlier Yanbulake culture (Chen and Hiebert 1995: 275) and the contemporary Sidaogou culture (Chen and Hiebert 1995: 272). An area of ten small stone mounds without any burials, reminiscent of a ritual locus, was also discovered near cemetery 4 . It seems likely, as Chen suggests (Chen and Hiebert 1995: 276), that the Chawuhu site was a regional centre, although whether it was an inhabited site or a ritual meeting place is unclear. This is supported by the uniformity of the Chawuhu zone's copper and bronze items, which suggest a common centre of production (Mei and Shell 1998: 589). The grave goods show some distinct continuity in the ceramic assemblage and a wide distribution of bronze items in styles similar to the earlier Xintala culture, but the introduction of iron items (mostly in the form of tools), and horses (Zhou 1998: 3) as well as gear for horse riding (Romgard 2008: 24) is a marked change. The ceramic assemblage, while showing continuity in style and technique, undergoes an interesting change as the previous white-purple/brown decoration gives way to black-on-red similar to that previously seen only in the Turfan depression (Chen and Hiebert 1995: 275). This black-on-red pottery seems to spread across the entire northern Tarim Basin and Tian Shan region, appearing for example in "Saka" sites across the Tian Shan (Chen and Hiebert 1995: 284), probably indicating increased contact. The "animal-style" motif known from the nearby steppe region also appears in the bronze objects, especially in horse bits and ornaments (Chen and Hiebert 1995: 275; Mei and Shell 1998: 588-9).

The other major site in the Chawuhu zone, the Alagou pebble graves (Wang 1981), lies at the very edge of the zone and has perhaps also been influenced by or connected to the cultures of the Turfan basin. The burials are similar to those at Chawuhu, with similar ceramics and burials of multiple individuals together, but with no agricultural implements, representing perhaps a pastoral community (Chen and Hiebert 1995: 278). Recent excavations nearby have, however, uncovered stone buildings suggesting a more sedentary community (Xinjiang Institute of Cultural Relics and Archaeology 2014). There is some disagreement in the literature on this point: Ma and Wang (1996: 206) suggest the pebble graves are closer to the Turfan cultures, based on burial practices. For this article this is less relevant, as what makes the Alagou graves interesting are the clear changes seen from the earlier to the later burials of the site, as determined by radiocarbon dating. The early graves show a very similar assemblage to Chawuhu, or indeed the earlier Xintala culture, with high-quality woollen textiles, wooden, stone and bronze tools, as well as artefacts of jade and other precious stones, cowries, bronze and gold. Besides some cowries and possibly gold, the only discernible item hailing from outside the Tarim Basin is a silk hairnet found with one of the deceased, an item which must almost certainly have come from China (Ma and Wang 1996: 206-8). Graves from later dates are, however, markedly different. First, the pattern of collective burials is completely replaced by graves of one or two individuals with a far richer assemblage, and though the basic structure of the tombs remained, wooden pillars and benches were added. Second, the bronze assemblage is largely replaced by iron items, showing clearly the beginning of the transition from bronze to iron in this period. Third, and of greatest interest, is the appearance of a large number of luxurious items of definitive foreign origin, many of which probably originated in China. 
The strongest evidence of this is significant quantities of silk, some embroidered with the pattern of the phoenix, which was common in China in this period, but also lacquerware which appears to be of Chinese origin (Ma and Wang 1996: 209-10). The Alagou graves are interesting because they show a transition from multiple burials with an almost entirely native assemblage, to individual graves furnished with a rich variety of imported prestige items. There are of course a variety of ways to explain changes in burial culture, but there is seemingly a strong case for arguing that it reflects an increasing stratification of the society as local leaders accumulated prestigious items and arranged for more spectacular burials.

The development in the Yanqi (Karashar) oasis area thus presents an intriguing picture of a changing region. The area around Yanqi (Karashar) seems to grow more integrated, perhaps with the Chawuhu site as a spiritual and/or regional centre, and one must assume this would also mean increased stratification, as the role of the leaders or priests keeping the various groups together grew in prominence. Evidence from Alagou strongly supports such an assumption and shows changes in burial practices and assemblage which most likely reflect increased stratification compared to the seemingly egalitarian Xintala culture. The evidence from Alagou also seems to indicate a change from communal to individual burials, which is probably indicative of a stronger focus on the individual, an important part of the transition towards more stratified societies both in Europe (Vandkilde 2007: 12-3) and the Americas (Flannery 1998: 46). The quality of the copper and bronze objects from the Chawuhu sites also suggests increased specialization, perhaps with full-time smiths. This is further supported by the aforementioned tendency towards standardization of metal items, suggesting a common origin or a centre of production. Furthermore, both the Chawuhu and Alagou sites show clear signs of increased connections with areas beyond the Tarim Basin. The appearance of large quantities of Chinese goods at the late Alagou graves shows that by the end of the late prehistoric period, contact with Chinese civilization had become a factor in the Tarim region, though in all likelihood indirectly so through intermediates in the Gansu area or Mongolian steppe. More marked, however, is the connection to the Steppe Zone, which is clear in both Chawuhu and Alagou burials and seen in the appearance of artefacts, for example gold and silver belt plaques with animal designs or a copper tray with animal figurines, whose match has been found in the Ili valley (Ma and Wang 1996: 211), most likely hailing from the Steppe Zone. And more prominently, it can been seen in the adaptation of horses and horse-riding technology, which is entirely new to the region. Appearing at the same time as iron, as well as new forms of burials, it seems as if a "Steppe Package" from the Steppe Zone was being adopted in the Yanqi (Karashar) oasis at the start of the last millennium BCE.

This influence does not appear to be limited to the northern Tarim Basin, as evidence from the Liushiu cemetery shows. Liushiu cemetery (RC dated 1100$900 \mathrm{BCE}$ ), located near the Keriya river in the Kunlun mountains, is thought to have been a cemetery used by a group of nomadic or semi-nomadic people during summer pasture. This group probably had strong ties to the agrarian communities further down the river's course, though it is unclear if they were themselves farmers during parts of the year (Wagner et al. 2011: 15736). The 
burials at Liushiu were marked by small stone mounds and the majority of the burials contained several individuals, probably the result of later communal reburials in a similar fashion to several other Tarim cultures. The material culture shows many similarities with that of the northern Tarim Basin as well as the Steppe Zone north of the Tianshan, though it has its own distinct pottery style shared with western Kunlun burials and also with Djoumboulak Koum (Wagner et al. 2011: 15735). Bronze has been found only in limited quantity and iron only in the form of slags, while the material remains are in general of an easily transportable type, further supporting the idea of a pastoral or nomadic community. The burials have also furnished horse-riding equipment as well as the skeletons of horses, proving that by the start of the first millennium $\mathrm{BCE}$, the technology of horse domestication and riding had reached the southern rim of the Tarim Basin (Wagner et al. 2011: 15734-7). Much like the discoveries from the Chawuhu site and the early Alagou site, some of which are probably contemporary with the Liushiu cemetery, the burials of Liushiu shows clear signs of connections with and influence from the Steppe Zone, both in aspects of their material culture, but most significantly in the adaptation of horse-riding technology. This confirms that the cultural, economic and material changes introduced from the Steppe Zone not only affected the northern Tianshan rim, but seem to have reached the entire Tarim region.

\section{Jumi - developing cities}

Where the finds at the Chawuhu sites give us glimpses of a changing Tarim Basin, the extraordinary finds at Djoumboulak Koum by the Keriya River show us something of the end point, namely the rise of the Tarim city-states mentioned in the Chinese accounts. Human habitation along the Keriya River has been traced back to the late Bronze Age period in the second millennium $\mathrm{BCE}$ and seems to have been dependent on the river for irrigated agriculture (Debaine-Francfort et al. 2010: 198). Several sites near the Keriya river show a similar development to the northern Tarim Basin, with an initial lack of foreign goods at the North Niya Site (2500-2000 BCE), some items of foreign origin at the previously mentioned Liushiu cemetery and finally what is clearly Chinese silk and lacquerware at the Zaghunluq site (700 BCE-100 CE) (Tang et al. 2013: 40).

The site of Djoumboulak Koum itself has been dated to around the fifth century $\mathrm{BCE}$ and probably represents a prototype for the later cities of antiquity. Situated along the river, Djoumboulak Koum was the centre of a large irrigated oasis area which could have supported a significant population, occupying some 94 discovered sites along a $40 \mathrm{~km}$ stretch of the river (Debaine-Francfort et al. 2010: 197). The site of the walled city itself covers an area of roughly 10 hectares with the mudbrick wall running some 720 metres. Within the perimeter, several large buildings have been excavated, some with outbuildings for animals and small siloes for storage, as well as cemeteries (Debaine-Francfort et al. 2010: 193-5). The sustenance basis of the settlement was farming-herding, with both cereals and animal products featuring heavily in the diet, showing a clear continuity from sites like Xintala. But archaeological remains, such as carnelian and linen dyed with cochineal (Debaine-Francfort, 2007: 7), found on the site show that the city was connected to the surrounding Tarim region as well as perhaps more distant connections with the Steppe Zone, China, Western Central 
Asia and even the Indian subcontinent, all of which must have been important links for the city's sustenance (Debaine-Francfort et al. 2010: 195). A site on the scale of Djoumboulak Koum, especially the massive walls and vast hinterland, would have required a high level of social complexity and stratification with various specialists to provide the necessary skills and tools. Though no palace or similar structure has been discovered as yet, the site was in all likelihood ruled by a king or similar leader, a predecessor of the later rulers who Chinese accounts confirm ruled the various Tarim polities. The late period of Tarim prehistory thus gives the impression of rapid and marked change which completely transformed the area, economically, socially and politically.

\section{The roots of the Silk Roads}

The changes observed above do beg the question of what caused this startling transformation of the area from what appears to have been small, apparently egalitarian and relatively isolated communities spread across the vast Tarim Basin, to larger political units with a clearly discernible stratification, and eventually to walled city-state-like polities. Scholars have suggested several possible explanations, which can be broadly grouped as: Chinese influence; climate change; and migration.

In what could be termed a traditional approach, Ma and Wang (1996: 218), discussing the changes seen in the Alagou pebble graves, have suggested that these changes were the result of the increasing influence of Chinese culture and economy. Indeed, it was during the period in question that some Chinese states, at the time divided into several states locked in intense internal competition and frequent spats of warfare during the Warring States Period, started expanding north and west (Di Cosmo 2006: 15). Yet in Chinese sources from the period there is little proof for contact with the Tarim Basin, let alone direct cultural influence. The very fractured and unstable nature of the Chinese states during much of the last millennium BCE also makes Ma and Wang's explanation seem less likely. That is not to say that resources and products of the Tarim Basin did not reach China during this period and vice-versa: Chinese tombs have furnished several jades from the Khotan (Yutian) area (Mei and Shell 1998: 593; Ming 2011: 52 and 68 for some examples). For instance the jade from the Western Zhou era (1046-771 BCE) found in the Guanzhong site contained several items made from Khotanese nephrite (Chen 2009). Yet Chinese contemporary writers of the time seemed to know little of where these items originated. As an example, the account Guanzi attributed to Guan Zhong, probably dating from the Warring States period (475-221 BCE), in several passages mentions jade as coming from territories bordering the Yuezhi and being traded to the Chinese by way of the Yuezhi, who at the time lived in Gansu north-west of China (Guan Zhong XXIII.78 and II.84.8 (425)). Yet the author says nothing more of the people beyond the Yuezhi and his knowledge of the regions seems hazy at best. Thus while Chinese goods certainly were valued commodities which found their way into and played an important role as novelties in the Tarim Basin, it hardly seems plausible to attribute later changes to direct Chinese influence.

Several scholars have recently looked at the climatic conditions of the Tarim Basin in order to explain some of the changes seen in the first and second 
millennia BCE (Debaine-Francfort et al. 2010; Hsü 1998; Wagner et al. 2011; Zu et al. 2003). However, there is as yet no clear consensus on the climatic patterns of the first millennium BCE, other than agreement that, by the end of this period, the climate was becoming drier and the rivers receding. But if many Tarim Basin settlements were based on irrigated agriculture it seems unlikely that these changes in precipitation and general climate would have affected them adversely, irrigated agriculture being far more resistant to such changes (Meyer 2013: 272-3). While changing climatic conditions could certainly have played a role, it seems unlikely to have been a major force of change across the region, and such a study would require an article of its own.

Another theory that has received much attention is a variation on the migration theories mentioned above, which essentially suggest that the changes seen in the Tarim Basin at the start of the first millennium BCE were due to the migration of new groups into the region (Chen and Hiebert 1995; Hemphill and Mallory 2004; Kuzmina 1998: $82-3) .{ }^{7}$ This theory is closely related to the second, steppe-focused tradition in Silk Road historiography and points mainly to parallels between the Tarim cultures' development and the development seen in the Steppe Zone. Emphasized in particular are the introduction of domesticated horses, horse-riding technology, iron metallurgy, kurgan-style burials and "animal-style" ornamentation, all innovations developing before or in parallel with the changes seen in the Tarim Basin. Yet several recent studies of the human remains from several Tarim Basin burials, both craniometrical and mtDNA analysis, show no signs of large-scale migration having taken place (Cui et al. 2009: 3921-2; Hemphill and Mallory 2004; Tan et al. 2013). A supposed migration also neglects the strong continuity seen in the Tarim Basin assemblages as underlined by Chen and Hiebert (1995: 283). Migration therefore seems to be a less likely explanation for the changes observed above.

This is not of course to say that migration could not have played a part in the introduction of new technologies and ideas into the Tarim Basin; it probably did. But instead of a large-scale migration model it seems prudent to suggest the spread of a "steppe package" of technological and cultural elements, quite possibly accompanied or carried by smaller migrating groups. In such a model the "package" would have spread into and across the Tarim Basin through various reciprocal forms of interaction and then adapted to the local environment, much as has been suggested with the "Neolithic package" across Europe (Vandkilde 2007, pt. 1). Just such a model is proposed by Michael Frachetti (2012: 17-21) as having led to the spread of these cultural and technological elements across the Steppe Zone in the first place. In particular, Frachetti emphasizes how this development was distinctly non-uniform in nature and that the various actors involved adopted only parts of this "package" (Frachetti 2012: 19). This last point is certainly clear in the case of the Tarim Basin, as, despite similar development, several areas retained distinct characteristics such as pottery style and burial practice.

7 See Hemphill and Mallory 2004: 217-8 for a full overview of the different suggestions and their proponents. 
This model of non-uniform development through increased interaction would also help explain other changes seen in the first millennium BCE, namely increased stratification, social complexity and accumulation of prestige goods and novelties. Sanders and Webster, in their thorough discussion on the development of complex societies, stress the importance of redistribution, i.e. that one person or a small group controls the internal distribution of important resources in a society, especially capital, land or water (Sanders and Webster 1978: 272). This mechanism is central to the explanation for the so called "Palace-Cultures" of the Eastern Mediterranean (Cunliffe 2008: 188-95). There, the monopolization of trade connections, especially for copper and tin, was the foundation of the king's power. Similarly Beckwith (2009: 26-28), Raschke (1978: 607-9) and Honeychurch (2015: 73-4) all hold that the central component of the later Central Asian nomadic empires was redistribution of valuable resources from the leader to his followers. In the context of the Tarim Basin it seems likely that here too control over the exchange of resources other than land or water was the main mechanism which saw the development of more complex societies, as has been argued for the Steppe Zone. It certainly fits very well with the available evidence from the Chawuhu and Alagou burials, where signs of increased stratification are accompanied by an increase in foreign prestige items.

This article would thus suggest that it was, first and foremost, increased interregional interaction which spurred the changes seen in the Tarim Basin during the late period of prehistory. This interaction probably took myriad forms, including migration, warfare, and alliances, matrimonial or otherwise. Warfare in particular is proposed as a possibility by Wagner et al. (2011: 15737), though evidence for this is still scant, and judging what role it could have played is therefore still difficult. But the most important mode of interaction apparent in the available sources seems to have been the exchange of resources.

Yet this conclusion also raises the questions of why these processes did not occur earlier, and how the Tarim Basin societies were drawn into them. After all, resources for exchange, such as metals or jade, were available and in regional use from as early as the second millennium BCE. What was new, however, was the introduction of domesticated horses, horse-riding technology and mounted pastoral nomads. People living as pastoral nomads existed long before the turn of the first millennium BCE, but mounted pastoralists, utilizing domesticated horses and horse-riding technology, are in general agreed to have appeared around the start of the first millennium BCE (Beckwith 2009; Honeychurch 2015; Raschke 1978; Renfrew 1998). Appearing first in the Steppe Zone to the north of the Tarim Basin and later, as shown by the Liushiu cemetery, within the Tarim Basin itself, this technology would have allowed people not only to traverse but also to inhabit many of the difficult and harsh regions surrounding the Tarim Basin. Michael Frachetti (2002: 1-2) notes that throughout the second millennium BCE, several groups moved into the previously uninhabited mountain steppe zones at the border of the Tarim Basin, mainly practising nomadic pastoralism. According to Frachetti, these groups controlled and facilitated exchange of resources such as copper with the population of the Steppe Zone proper, occupying natural transit zones such as the Dzungarian Gate north-west of Yanqi (Karashar) (Frachetti 2002: 8). Similarly, Chinese written sources from the period denote the nomadic Yuezhi, 
probably living as mounted nomadic pastoralists in Gansu and the Hexi Corridor, as the main traders in jade (Guan Zhong, XXIII.78 and II.84.8 (425)). Bridging the inhospitable gaps between the various regions in eastern Central Asia, these mounted nomadic groups would have allowed items and resources to cross far larger distances in a shorter span of time, facilitating exchange not only between the Tarim Basin and the Steppe but probably also with areas east and west. Though certainly the early exchange would have been less organized and intended to cover the internal demand in the group, perhaps even taking the form of gift-exchange, these local exchange connections would perhaps in time also have turned into more "trade-like" connections befitting the term long-distance exchange.

It also seems likely that these growing interregional networks of interaction and exchange grew out of the smaller regional contacts described in the first section of this article. While tin and copper seem not to have been important resources for long-distance exchange either in the Tarim Basin or the nearby regions, at least judging from their availability (Penhallurick 2008, ch. 1; Mei and Shell 1998: 594), metals could, however, have been a commodity for local exchange on a regional scale. In particular the previously mentioned connection across the Tian Shan could well have had metal as a central resource for exchange. Nor can we entirely preclude the possibility that metals and metal artefacts were exchanged with the Gansu corridor and the Mongolian steppes. Agricultural surplus, the basis of the sedentary Tarim settlements, could certainly have been traded with the nomadic pastoral groups both within and beyond the Tarim Basin, especially cereals, which as Laszlo Torday (1997: 12-3) points out could be stored and thus used by the nomads in the lean winter months. This steppe-oasis trade must have flourished with the appearance of mounted pastoral nomadism and was probably the connection which brought the "steppe package" into the Tarim Basin. Textiles, especially wool, but also linen from flax, could also have been an important product for exchange in the steppe-oasis trade. These textiles, while perhaps not as desirable for the nomads surrounding the Tarim Basin, were in great demand in the Chinese states where the widespread availability of silk made wool a more prestigious commodity (Boulnois 1966: 19). Dyed in various bright colours and artfully woven, these items appear to have been considered fairly valuable in China at the time, and have been discovered in tombs of the Han period (Ma and Sun 1996: 230-2). An ode from the Shijing (Classic of Poetry) furthermore illustrates the low worth ascribed to silk compared to other cloth during the seventh century BCE (Shijing, Odes of Wei, Mang). The abundance of sheep kept and wool produced at Djoumboulak Koum further underlines the importance of these textiles for the city's economy (Debaine-Francfort et al. 2010: 195). The Tarim Basin's most important commodity for exchange, however, was probably precious stones, especially jade. Jade has since ancient times had a central place in Chinese culture as an object of great value, thought to contain the secret to mortality and have other magical properties (Lin 2012a: 80). Perhaps the best examples of the value and importance attached to jade can be seen in the Han period burials such as that of the king of Yue who was buried in a jade coffin wearing a full jade suite and with his nine orifices plugged by jade plugs, all to preserve his body and help him in the afterlife (Lin, 2012b: 82-7). The 
Hanshu by Ban $\mathrm{Gu}$, written in the first century $\mathrm{CE}$, reports no fewer than five kingdoms in the Tarim Basin which produce jade; in particular, Yutian (Khotan) is highlighted as having an abundance of jadestone, and Souju (Yarkand), which produces blue-green jade (Ban Gu, 96A: (97) (140)). Much of the early jade found in China is the pale nephrite jade from Yutian (Khotan) and Souju (Yarkand), showing clearly that the jade played an important role in the connections between China and the Tarim Basin already in the late prehistoric period. Furthermore, during the Warring States period (fifthsecond centuries BCE), jade from Khotan seems to become increasingly abundant in Chinese tombs (Ming 2011: 68), coinciding with the development outlined in this article. Jade from the Tarim Basin has also been found in significant quantities in many nomad tombs throughout the Steppe Zone such as at Chust in Ferghana, also here considered a valued commodity (Kuzmina 1998: 82).

\section{The nascent Silk Road}

By tracing the development of two oasis areas in the Tarim Basin through the last two millennia BCE we see a marked change which seems to have started in the last centuries of the second millennium. From a Tarim Basin settled by smaller, relatively egalitarian, agricultural societies connected by limited exchange networks there is a transition to larger cultural zones with signs of growing stratification and vigorous exchange both within the region and beyond, ending with the development of city-states towards the end of the first millennium BCE. While there must certainly have been local adaptations and variation, this development seems to be fairly uniform across the whole of the Tarim Basin, at both the northern sites around Yanqi (Karashar) and the southern ones near the Keriya River. Though several factors contributed to this development: population growth, warfare, migration and possibly changing climatic conditions, among others, it seems clear to me that the single most important factor was an increase in exchange and contact with surrounding regions. This increase in interaction was made possible by the invention of horseback riding and the associated technologies. Through the control over exchange local chiefs and leaders could have built a more reliable power base through redistribution of novel resources to their followers, creating both increased stratification in the Tarim societies and eventually cementing their positions into more permanent ones towards the end of the period. The exchange network which resulted from the development sketched above would have stretched from the Central Plains of China to Siberia in the north and the Tarim Basin in the west, indeed probably even further, forming the eastern Central Asian exchange network. In time, through connection with other, similar networks, this would have formed one of the foundations of the greater Silk Road exchange network.

To return to the initial research questions, this article has shown that as the smaller Tarim communities were introduced to a wider regional and interregional context of interaction and exchange, this opened up the possibility for increased social stratification and institutional complexity. Yet at the same time, the Tarim Basin communities were not passive recipients of goods, innovations and cultural influence. Rather they must be understood as an active part of a larger interregional network, and precisely the changes in social complexity 
and stratification they underwent would have further spurred the development of the interregional network. These two processes, increasing complexity and the growth of the interregional network, were mutually reinforcing and led to the rapid development seen in the first millennium BCE.

This conclusion has important implications for the original debate of who or what drove the development of the early Silk Road exchange. As this article has attempted to demonstrate, it is too simple a solution to suggest that exchange across the vast trans-Eurasian Silk Road network had a single driving force or instigating factor, whether the nomads of Beckwith or the empires of Liu and McLaughlin. As recognized by several recent scholars of the nomadic pastoralist peoples of Central Asia, the region's development was closely tied to increasing exchange and mobility. Thus rather than one single instigator of large-scale exchange along the eastern part of the Silk Road trade network, its development was a gradual process with its roots in the regional and interregional exchange networks of prehistory. Its development was not only driven by the nascent polities of the Steppe, Tarim Basin or China, but was also vital to their internal development, explaining, I believe, much of its vigour and tremendous success.

\section{Bibliography}

\section{Primary sources}

Ban Gu. 1979. Hanshu [漢書]. China in Central Asia, The Early Stage: 125 B.C.-A.D. 23 (trans. A.F.P. Hulsewe with an introduction by M.A.N. Loewe). Leiden: E.J. Brill.

Fan Ye. 2009. Hou Hanshu [後漢書]. Through the Jade Gate to Rome: A Study of the Silk Routes during the Later Han Dynasty 1st to 2nd Centuries CE. An Annotated Translation of the Chronicle on the "Western Regions" in the Hou Hanshou (trans. John E. Hill). Lexington: Book Surge Publishing.

Guan Zhong. 2001. Guanzi [管子]. Political, Economic, and Philosophical Essays from Early China (trans. Allyn W. Rickett). Boston: Cheng \& Tsui Company.

Pliny the Elder. 1855. Naturalis Historia (trans. John Bostock and H.T Riley). London: Taylor and Francis. http://www.perseus.tufts.edu/hopper/text?doc $=$ Perseus\%3atext\% 3a1999.02.0137

Shijing. "Odes of Wei, Mang" (trans. James Legge). http://ctext.org/book-of-poetry/ mang? searchu $=$ silk\&searchmode $=$ showall\#result

\section{References}

An, Z. 1998. "Cultural complexes of the Bronze Age in the Tarim Basin and surrounding areas", in V.H. Mair (ed.), The Bronze Age and Early Iron Age Peoples of Eastern Central Asia. Philadelphia: The University of Pennsylvania Museum Publications, 45-62.

Anthony, D.W. 1998. "The opening of the Eurasian steppe at 2000 BCE", in V.H. Mair (ed.), The Bronze Age and Early Iron Age Peoples of Eastern Central Asia. Philadelphia: The University of Pennsylvania Museum Publications, 94-113.

Beckwith, C.I. 2009. Empires of the Silk Road: A History of Central Eurasia from the Bronze Age to the Present. Princeton: Princeton University Press.

Boulnois, L. 1966. The Silk Road. London: Allen \& Unwin.

Chen, K. and F.T. Hiebert. 1995. "The late prehistory of Xinjiang in relation to its neighbors", Journal of World Prehistory 9, 243-300. doi: 10.1007/BF02221840 
Chen, Z. 2009. "On the date of the eastward export of Xinjing Hotan jade to the hinterland” (关于新疆和田玉东输内地的年代问题). Kaogu (Archaeology), 81-3.

Christian, D. 2000. "Silk roads or Steppe roads? The silk roads in world history", Journal of World History 11, 1-26.

Cui, Y., S. Gao, C. Xie, Q. Zhang, H. Wang, H. Zhu and H. Zhou. 2009. "Analysis of the matrilineal genetic structure of population in the early Iron Age from Tarim Basin, Xinjiang, China", Chinese Science Bulletin 54, 3916-23. doi: 10.1007/ s11434-009-0647-8

Cunliffe, B. 2008. Europe between the Oceans. New Haven and London: Yale University Press.

Davis-Kimball, J. 1998. "Tribal interaction between the early Iron Age nomads of the southern Ural steppe, Semirechiye and Xinjiang”, in V.H. Mair (ed.), The Bronze Age and Early Iron Age Peoples of Eastern Central Asia. Philadelphia: The University of Pennsylvania Museum Publications, 238-63.

Debaine-Francfort, C. 2007. La Keriya dans tous ses états: modes de peuplement et paléoenvironnements. Presented at the 3ème Congrès du Réseau Asie - IMASIE, Paris.

Debaine-Francfort, C., F. Debaine and A. Idriss. 2010. "The Taklimakan oases: an environmental evolution shown through geoarchaeology", in G. Schneier-Madanes and M.-F. Courel (eds), Water and Sustainability in Arid Regions. Dordrecht: Springer Netherlands, 181-202.

Di Cosmo, N. 2014. "A note on the formation of the 'Silk Road' as long-distance exchange network", in M. Bulut (ed.), ReSilkroad. Istanbul: Istanbul Sabahattin Zaim University Publications, 17-26.

Di Cosmo, N. 2006. "The origin of the Great Wall”, The Silk Road 4, 14-9. http://silkroadfoundation.org/toc/newsletter.html

Di Cosmo, N. 2000. "Ancient city-states of the Tarim Basin”, in M.H. Hansen (ed.), A Comparative Study of Thirty City-State Cultures: An Investigation. Copenhagen: C.A. Reitzels Forlag.

Ferguson, J. and M. Keynes. 1978. "China and Rome", in H. Temporini and W. Haase (eds), Aufstieg und Niedergang der römischen Welt. Berlin: Walter de Gruyter, 581-603.

Flannery, K.V. 1998. "The ground plans of archaic states", in G.M. Feinman and J. Marcus (eds), Archaic States. Santa Fe: School of American Research Press.

Frachetti, M. 2002. "Bronze Age exploitation and political dynamics of the eastern Eurasian steppe zone", in K. Boyle, C. Renfrew, and M. Levine (eds), Ancient Interactions: East and West in Eurasia. Cambridge: McDonald Institute for Archaeological Research, 161-70.

Frachetti, M.D. 2012. "Multiregional emergence of mobile pastoralism and nonuniform institutional complexity across Eurasia", Current Anthropology 53, 2-38. doi: 10.1086/663692

Frachetti, M.D. 2011. "Migration concepts in central Eurasian archaeology", Annual Review of Anthropology 40, 195-212. doi: 10.1146/annurev-anthro-081309-145939

Han, J. 2012. “'The painted pottery road' and early Sino-Western cultural exchange”, Anabasis, 25-42.

Hansen, M.H. (ed.). 2000. A Comparative Study of Thirty City-State Cultures: An Investigation. Copenhagen: C.A. Reitzels Forlag.

Hansen, V. 2012. The Silk Road: A New History. Oxford: Oxford University Press.

Hemphill, B.E. and J.P. Mallory. 2004. "Horse-mounted invaders from the Russo-Kazakh steppe or agricultural colonists from western Central Asia? A 
craniometric investigation of the Bronze Age settlement of Xinjiang", American Journal of Physical Anthropology 124, 199-222. doi: 10.1002/ajpa.10354

Hill, J.E. 2015. Through the Jade Gate: China to Rome. A Study of the Silk Routes during the Later Han Dynasty 1st to 2nd centuries CE (First edition). Lexington: Book Surge Publishing.

Honeychurch, W. 2015. Inner Asia and the Spatial Politics of Empire. Archaeology, Mobility and Cultural Contact. New York: Springer.

Hsü, K.J. 1998. "Did the Xinjiang Indo-Europeans leave their home because of global cooling?", in V.H. Mair (ed.), The Bronze Age and Early Iron Age Peoples of Eastern Central Asia. Philadelphia: The University of Pennsylvania Museum Publications, 683-98.

IAX (Institute of Archaeology of the Xinjiang Academy of Social Sciences). 1988. “Excavation of the Xintala site, Heshuo, Xinjiang” (新疆和硕新塔拉遗址发掘简报). Kaogu (Archaeology), 399-407.

Jiang, H., Y. Wu, H. Wang, D.K. Ferguson and C.-S. Li. 2013. "Ancient plant use at the site of Yuergou, Xinjiang, China: implications from desiccated and charred plant remains", Vegetation History and Archaeobotany 22, 129-40. doi: 10.1007/ s00334-012-0365-z

Kuzmina, E.E. 1998. "Cultural connections of the Tarim Basin people and pastoralists of the Asian steppe in the Bronze Age", in V.H. Mair (ed.), The Bronze Age and Early Iron Age Peoples of Eastern Central Asia. Philadelphia: The University of Pennsylvania Museum Publications, 63-93.

Kuzmina, E.E. 2008. The Prehistory of the Silk Road. Philadelphia: University of Pennsylvania Press.

Lin, J. 2012a. "Treasures from the underground palace: tomb treasures of Han China", Art of Asia 42, 69-81.

Lin, J. 2012b. "The Emperor's new clothes: dressing for the afterlife", Art of Asia 42, $82-9$.

Liu, X. 2010. The Silk Road in World History. New York: Oxford University Press.

Ma, Y. and Y. Sun. 1996. "The western regions under the Hsiung-nu and the Han", in J. Harmatta (ed.), History of Civilizations of Central Asia Vol. 2. Paris: UNESCO Publishing, 227-46.

Ma, Y. and B. Wang. 1996. "The culture of the Xinjiang region”, in J. Harmatta (ed.), History of Civilizations of Central Asia Vol. 2. Paris: UNESCO Publishing, 209-25.

Mair, V.H. 1995. "Mummies of the Tarim Basin", Archaeology, 48, 28-35.

McLaughlin, R. 2010. Rome and the Distant East: Trade Routes to the Ancient Lands of Arabia, India and China. London: Continuum.

Mei, J. and C. Shell. 1998. "Copper and bronze metallurgy in late prehistoric Xinjiang", in V.H. Mair (ed.), The Bronze Age and Early Iron Age Peoples of Eastern Central Asia. Philadelphia: The University of Pennsylvania Museum Publications, 581-603.

Mei, J., P. Wang, K. Chen, L. Wang, Y. Wang and Y. Liu. 2015. "Archaeometallurgical studies in China: some recent developments and challenging issues", Journal of Archaeological Science 56, 221-32. doi: 10.1016/j.jas.2015.02.026

Meyer, J.C. 2013. "City and hinterland: villages and estates north of Palmyra. New perspectives", Studia Palmyreńskie, 269-85.

Ming, Y. 2011. Chinese Jade. Cambridge: Cambridge University Press.

Peng, K. 1998. "The Andronovo bronze artifacts discovered in Toquztara County in Ili, Xinjiang”, in V.H. Mair (ed.), The Bronze Age and Early Iron Age Peoples of Eastern Central Asia. Philadelphia: The University of Pennsylvania Museum Publications, 573-80. 
Penhallurick, R.D. 2008. Tin in Antiquity: Its Mining and Trade throughout the Ancient World with Particular Reference to Cornwall. Leeds: Maney Publishing.

Rapp, G. 2009. "Metals and related minerals and ores", in Archaeomineralogy. Berlin and Heidelberg: Springer, 143-82.

Raschke, M.G. 1978. "New studies in Roman commerce with the East", in H. Temporini and W. Haase (eds), Aufstieg und Niedergang der römischen Welt. Berlin: Walter de Gruyter, 604-1361.

Renfrew, C. 1998. "The Tarim Basin, Tocharian, and Indo-European origin: a view from the West", in V.H. Mair (ed.), The Bronze Age and Early Iron Age Peoples of Eastern Central Asia. Philadelphia: The University of Pennsylvania Museum Publications, 202-14.

Romgard, J. 2008. "Questions of ancient human settlement in Xinjiang and the early Silk Road trade, with an overview of Silk Road research institutions and scholars in Beijing, Gansu and Xinjiang", Sino-Platonic Papers, 3-119. Available at: http:// www.sino-platonic.org/

Sanders, W.T. and D. Webster. 1978. "Unilinealism, multilinealism, and the evolution of complex societies", in C.L. Redman (ed.), Social Archeology, Beyond Subsistence and Dating. New York: Academic Press.

Stein, M.A. 1903. Sand-Buried Ruins of Khotan. London: T. Fisher Unwin.

Tang, Z., D. Chen, X. Wu and G. Mu. 2013. "Redistribution of prehistoric Tarim people in response to climate change", Quaternary International 308-9: 36-41. doi: 10.1016/j.quaint.2013.01.021

Tan, J., L. Li, J. Zhang, W. Fu, H. Guan, X. Ao, L. Wang, X. Wu, K. Han, L. Jin and H. Li. 2013. "Craniometrical evidence for population admixture between eastern and western Eurasians in Bronze Age southwest Xinjiang", Chinese Science Bulletin 58, 299-306. doi: 10.1007/s11434-012-5459-6

Thorley, J. 1969. "The development of trade between the Roman Empire and the East under Augustus", Greece and Rome (Second Series) 16, 209-23.

Thorley, J. 1971. "The silk trade between China and the Roman Empire at its height, circa AD 90-130", Greece and Rome (Second Series) 18, 71-80.

Thorley, J. 1979. "The Roman Empire and the Kushans", Greece and Rome (Second Series) 26, 181-90.

Torday, L. 1997. Mounted Archers: The Beginnings of Central Asian History. Durham: Durham Academic Press.

Vandkilde, H. 2007. Culture and Change in Central European Prehistory. Aarhus: Aarhus University Press.

Wagner, M., X. Wu, P. Tarasov, A. Aisha, C.B. Ramsey, M. Schultz, T. Schmidt-Schultz and J. Gresky. 2011. "Radiocarbon-dated archaeological record of early first millennium B.C. mounted pastoralists in the Kunlun Mountains, China", Proceedings of the National Academy of Sciences 108: 15733-8. doi: 10.1073/pnas. 1105273108

Wang, B. 1981. "Excavation report of the vertical-pit wooden coffin chamber tombs of Alagou in Xinjiang” (新疆阿拉沟坚穴木撑墓发掘简报), Wenwu, 18-22.

Wang, Helen. 2004. Money on the Silk Road: The Evidence from eastern Central Asia to c. $A D$ 800. London: British Museum Press.

XAT (Xinjiang Archaeology Team), Administration for the Preservation of Ancient Monuments, Bayingolin Autonomous Mongolian Prefecture, Xinjiang. 1990a. “Excavation of Cemetery No. 2 at Chawuhu Pass, Hejing, Xinjiang” (新疆和静县 察吾乎沟口二号墓地发掘简报), Kaogu (Archaeology), 511-8. 
XAT (Xinjiang Archaeology Team), Administration for the Preservation of Ancient Monuments, Bayingolin Autonomous Mongolian Prefecture, Xinjiang. 1990b. "Excavation of Cemetery No. 3 at Chawuhu Pass, Hejiang County, Xinjiang" (新 碑和静粤察吾乎沟口三号墓地发掘简报), Kaogu (Archaeology), 882-9.

XAT (Xinjiang Archaeology Team), Administration for the Preservation of Ancient Monuments, Bayingolin Autonomous Mongolian Prefecture, Xinjiang. 1988. Cemetery No.1 at Chawuhu Pass, Hejing County, Xinjiang (新疆和静县察吾乎沟 口一号墓地), Kaogu Xuebao, 75-99.

Xinjiang Institute of Cultural Relics and Archaeology. 2014. "The Yu'ergou site and Alagou Cemetery in Urumqi City” (乌鲁木齐市鱼儿沟遗址与阿拉沟墓地), Kaogu (Archaeology), 19-35.

Zhang, Y. 1998. "The ancient cemetery of Alagou (Awrighul), Tianshan, Xinjiang Province: R.C.", Circle of Inner Asian Art: Newsletter, 13-5.

Zhao, K., X. Li, X. Zhou, J. Dodson and M. Ji. 2013. "Impact of agriculture on an oasis landscape during the late Holocene: palynological evidence from the Xintala site in Xinjiang, NW China", Quaternary International 311, 81-86. doi: 10.1016/j. quaint.2013.06.035

Zhou, J. 1998. "The Chawuhu culture in Xinjiang", Circle of Inner Asian Art: Newsletter, 3-6.

Zu, R., Q. Gao, J. Qu and M. Qiang. 2003. "Environmental changes of oases at southern margin of Tarim Basin, China”, Environmental Geology 44, 639-44. doi: 10.1007/ s00254-003-0808-z

\section{Appendix 1}

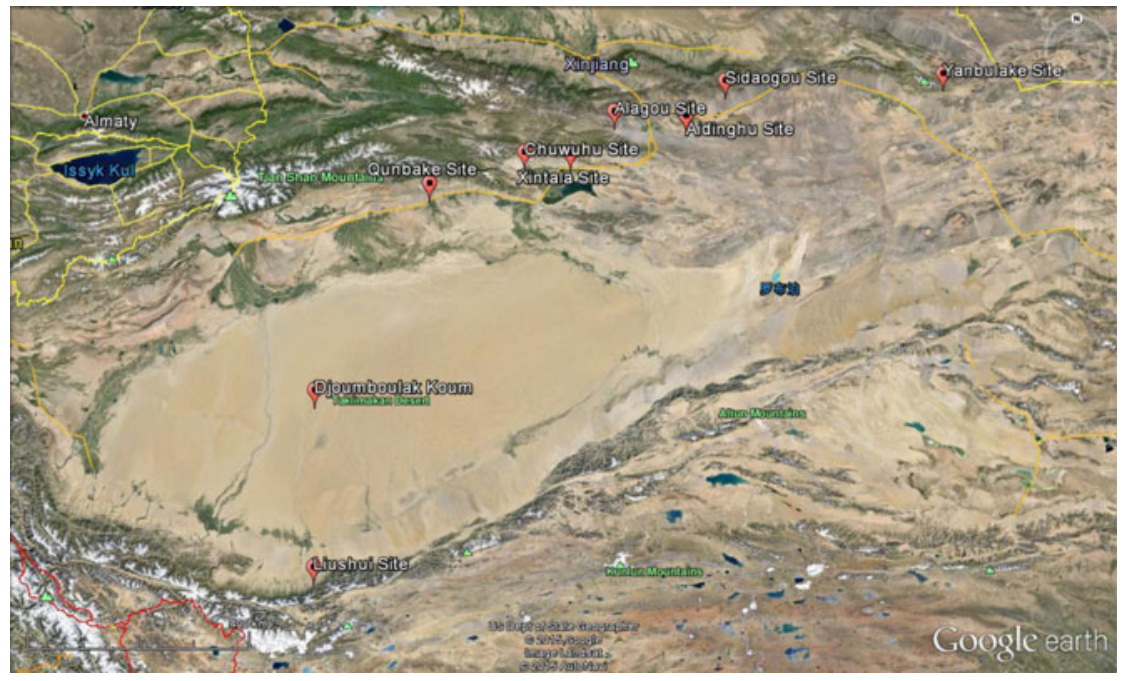




\section{Appendix 2}

\begin{tabular}{|c|c|c|c|c|}
\hline Site (with reports) & Mortuary practices & Local products & Regional products & Exotic/Novelties \\
\hline $\begin{array}{l}\text { Xintala (Chen and } \\
\text { Hiebert 1995; IAX } \\
\text { 1988; Mei and Shell } \\
\text { 1998) }\end{array}$ & $\begin{array}{l}\text { Unknown } \\
\text { Nearby sites of Yanbulake } \\
\text { and Aidinghu have various } \\
\text { mortuary practices, both } \\
\text { communal and couple } \\
\text { burials, yet little in the way } \\
\text { of monumentalism }\end{array}$ & $\begin{array}{l}\text { White slipped } \\
\text { redware pottery } \\
\text { Stone agricultural } \\
\text { tools (mortar, stone } \\
\text { hammer, etc.) }\end{array}$ & $\begin{array}{l}\text { Awl and knife of copper } \\
\text { Socketed axe, arrowhead } \\
\text { and awl of bronze } \\
\text { Stone mould for casting } \\
\text { copper }\end{array}$ & Nephrite axe \\
\hline $\begin{array}{l}\text { Chawuhu (Chen and } \\
\text { Hiebert 1995; Mei } \\
\text { and Shell 1998; XAT } \\
\text { 1990a; 1990b; 1988) }\end{array}$ & $\begin{array}{l}\text { Joint secondary burials } \\
\text { Stone enclosures and burial } \\
\text { mounds over } \\
\text { stone-chambered vertical } \\
\text { pits } \\
\text { Sometimes surrounded by } \\
\text { ox or horse-head pits } \\
\text { Stone mounds with painted } \\
\text { stones and no burials } \\
\text { (Cemetery } 4 \text { ) }\end{array}$ & $\begin{array}{l}\text { Redware and some } \\
\text { painted black-on-red } \\
\text { pottery } \\
\text { Stone, wood and } \\
\text { bone agro-pastoral } \\
\text { tools (arrowheads, } \\
\text { mortars, whorls, } \\
\text { basins, etc.). Woollen } \\
\text { textiles }\end{array}$ & $\begin{array}{l}\text { Large assemblage of } \\
\text { bronze tools and weapons } \\
\text { (arrowheads, spearheads, } \\
\text { knives, belt-buckles, } \\
\text { horse-bits, one "ritual" } \\
\text { bowl and awls) } \\
\text { Iron tools (limited } \\
\text { amounts in Cemetery II, } \\
\text { almost only iron in } \\
\text { Cemetery III) } \\
\text { Bronze and iron } \\
\text { ornaments (plaques, } \\
\text { rings, earrings, brooches), } \\
\text { some of which are } \\
\text { decorated with } \\
\text { "animal-style" motifs }\end{array}$ & $\begin{array}{l}\text { Decorated bronze mirror } \\
\text { Gold and silver ornaments } \\
\text { and jewellery (rings, } \\
\text { ear-rings, brooches), some } \\
\text { of which are decorated } \\
\text { with "animal-style" motifs } \\
\text { in the younger cemeteries } \\
\text { (Cemetery III) } \\
\text { Horses (skulls, tailbones } \\
\text { and hoofs in separate pits) }\end{array}$ \\
\hline
\end{tabular}


Alagou early graves (Ma and Wang 1996; Wang 1981; Xinjiang Institute of Cultural Relics and

Archaeology 2014; Zhang 1998)

Alagou later graves (Ma and Wang 1996;

Wang 1981; Zhang 1998)

Four graves, have

been disturbed
Joint secondary burial later Stone enclosures and burial mounds over stone-chambered vertical pits covered by wood

Single or double burials Stone enclosures and burial mounds over wood-chambered vertical pits
Black-on-red painted pottery

Stone, wood and bone tools (bowls, whorls, fire-drills, etc.)

Mainly plain pottery and a few examples of painted pottery

Woollen textiles, dyed in three colours and patterned
Large assemblage of bronze tools (arrowheads, knives etc.)

Few iron tools (a needle, some slag remains of

iron)

Bronze ornaments

(brooches, plaques and ear-rings), some of which are decorated with "animal-style" motifs

\section{Iron knives}

Bronze ornaments and

trays
Agate and jade beads

Cowry shell ornaments

Gold earrings (one with an attached stone)

Silk textiles (a silk hairnet, an embroidered piece showing what is believed to be a phoenix)

Pearl and agate ornaments

Gold and silver ornaments (plaques and brooches, several with

"animal-style" motifs)

Lacquerware (a painted tray and a cup) 